Contents list available at IJRED website

Int. Journal of Renewable Energy Development (IJRED)

Journal homepage: http://ejournal.undip.ac.id/index.php/ijred

\title{
Biodiesel from Mustard oil: a Sustainable Engine Fuel Substitute for Bangladesh
}

\author{
M.M. Alam* and K.A. Rahman
}

Mechanical Engineering Department, Bangladesh University of Engineering \& Technology (BUET),

\author{
Dhaka-1000, BANGLADESH
}

\section{Article history:}

Received August 20, 2013 Received in revised form Sept. 18, 2013 Accepted September 27, 2013 Available online

\begin{abstract}
Various attractive features of mustard oil based biodiesel as a potential substitute for engine fuel are investigated in this paper for use in Bangladesh. Although the use of mustard oil as edible oil has been reduced, Bangladesh still produces 0.22 million metric tons of mustard oil per year. This surplus mustard oil would satisfactorily be used as an alternative to diesel fuel, and thus could contribute in reducing the expenses for importing fuel from foreign countries. Moreover, the rural people of Bangladesh are capable of producing mustard oil themselves using indigenous machines. Fuel properties of biodiesel obtained from mustard oil were determined in the laboratory using standard procedure and an experimental setup was constructed to study the performance of a small diesel engine. It is observed that with biodiesel, the engine is capable of running without difficulty. Initially different lower blends of biodiesel (e.g., B20, B30 etc.) have been used to avoid complicated modification of the engine and the fuel supply system. It is also found in some condition that mustard oil based biodiesel have better properties than those made from other vegetable oils. These properties of mustard oil based biodiesel were evaluated to validate its sustainability in Bangladesh.
\end{abstract}

Keywords: biodiesel, indigenous machines, mustard oil, renewable energy policy, sustainability

\section{Introduction}

In Bangladesh mustard seeds are cultivated in plenty and every year the production of mustard seed exceeds its demand (Hasib et al. 2011a). This is because of the fact that for a long time mustard oil had been extensively used as cooking oil throughout the country but due to its strong pungent smell for contained allyl isothiocyanate, it is replaced by neutrally flavored and comparatively cheaper (at that time) soybean oil. Many western countries including the US consider mustard oil as unsuitable for human consumption and have banned the use of Indian mustard oil as it has a high content of erucic acid and glucosinolates (Batra 2003). With these properties of mustard oil and the availability of cheaper oils, day by day mustard oil lost its popularity as edible cooking oil.

Although per-capita generation of electricity is increased during the last decade in Bangladesh, it is still very low compared to present demand (Bangladesh Bereau of Statistics 2011). The present power generation system of Bangladesh mainly depends on imported fossil fuels and natural gas. Last year Bangladesh spent about 823.7 million U.S. dollar for importing crude oil (Alam et al. 2010). To reduce the dependency on imported fuel, recently a "Renewable Energy (RE) Policy of Bangladesh" is prepared by the government targeting to develop renewable energy resources to meet $5 \%$ of the total power demand by the year 2015 and $10 \%$ by the year 2020. According to Section 2(ix) of the RE Policy, diversified and locally available sources of energy are being studied (Ehsan et al. 2007; Forhad et al. 2009; Hasib et al. 2011b) in the department of Mechanical Engineering of Bangladesh University of Engineering and Technology (BUET) for feasibility. Studies on cost effectiveness and pollution characteristics of this biodiesel are also going on at BUET (Uddin 2013). Since small diesel engines are

* Corresponding author:

E-mail: mmalam@me.buet.ac.bd; prof.alam@gmail.com 
commonly used in the villages for water pumping systems and standby electricity generators, use of diesel fuel is much higher than any other gasoline fuels in Bangladesh. This paper shows various attractive features of mustard oil which could make it one of the most significant sustainable renewable resources in the context of Bangladesh.

\section{Vegetable Oil as Engine Fuel}

Pure vegetable oil was first tested as fuel for diesel engine by the inventor of diesel engine Rudolph Diesel himself around a century ago (Arjun \& Islam 2008). Vegetable oils have started their use as substitutes for diesel fuels in emergency situations as early as in 1930 (Mani 2010). The use is closely related to its availability and price. Unlike fossil diesel, vegetable oil is biodegradable, nontoxic and almost free from Sulphur. Due to recent decline of fossil fuel reserve and as a consequence, increase in its price, many countries are now trying to use their native vegetable oils as alternative fuel sources. Fresh oil could be used in diesel engines with some engine modifications or modified oil (as biodiesel) could be used in unmodified engines. Over the past 10 to 20 years, researches regarding biodiesels were concentrated on ethanol and their use in light-duty gasoline engines, in recent years experiments relating to biodiesels were focused for blending them with diesel fuel and their use in compression ignition engines. For instance, soybean oil in U.S.A., rapeseed and sunflower oil in Europe, palm oil in Malaysia and Indonesia, coconut oil in Philippines (Srivastava \& Prasad 2000). In the same way mustard oil has its huge potential to be used as an alternative to diesel fuel in Bangladesh. The general benefits of using vegetable oils as engine fuels may be listed as follows:

- Vegetable oils are renewable

- They can be grown in marginal lands

- They have the potential to reduce the pollutants

- They have about $90 \%$ of the energy content of diesel

There are problems associated with using vegetable oils directly in conventional diesel engines. The problems are related to the type and grade of oil as well as the local climatic conditions. Vegetable oils are extracted from plants, the basic constituents of which are triglycerides. Triglycerides are esters of 3 long chain acids, commonly called fatty acids with a glycerol. Vegetable oils contain 90 to $98 \%$ triglycerides and small amount of mono and diglycerides. Fatty acids vary in their carbon chain length and in the number of double bonds. The fatty acids which are commonly found in vegetable oils are stearic, palmitic, oleic, linoleic and linolenic. The chemical formulae of common fatty acids are given in Table 1.
Table 1

Chemical structure of common fatty acids

\begin{tabular}{|c|c|c|c|}
\hline Fatty acid & Systematic name & $\begin{array}{c}\text { Structure } \\
x: y\end{array}$ & Formula \\
\hline Lauric & Dodecanoic & $12: 0$ & $\mathrm{C}_{12} \mathrm{H}_{24} \mathrm{O}_{2}$ \\
\hline Myristic & Tetradecanoic & $14: 0$ & $\mathrm{C}_{14} \mathrm{H}_{28} \mathrm{O}_{2}$ \\
\hline Palmitic & Hexadecanoic & $16: 0$ & $\mathrm{C}_{16} \mathrm{H}_{32} \mathrm{O}_{2}$ \\
\hline Stearic & Octadecanoic & $18: 0$ & $\mathrm{C}_{18} \mathrm{H}_{36} \mathrm{O}_{2}$ \\
\hline Arachidic & Eicosanoic & $20: 0$ & $\mathrm{C}_{20} \mathrm{H}_{40} \mathrm{O}_{2}$ \\
\hline Behenic & Docosanoic & $22: 0$ & $\mathrm{C}_{22} \mathrm{H}_{44} \mathrm{O}_{2}$ \\
\hline Lignoceric & Tetracosanoic & $24: 0$ & $\mathrm{C}_{24} \mathrm{H}_{48} \mathrm{O}_{2}$ \\
\hline Oleic & cis-9-Octadecenoic & $18: 1$ & $\mathrm{C}_{18} \mathrm{H}_{34} \mathrm{O}_{2}$ \\
\hline Linoleic & $\begin{array}{l}\text { cis-9,cis-12- } \\
\text { Octadecadienoic }\end{array}$ & $18: 2$ & $\mathrm{C}_{18} \mathrm{H}_{32} \mathrm{O}_{2}$ \\
\hline Linolenic & $\begin{array}{l}\text { cis-9, cis-12, cis-15- } \\
\text { Octadecatrienoic }\end{array}$ & $18: 3$ & $\mathrm{C}_{18} \mathrm{H}_{30} \mathrm{O}_{2}$ \\
\hline Erucic & cis-13-Docosenoic & $22: 1$ & $\mathrm{C}_{22} \mathrm{H}_{42} \mathrm{O}_{2}$ \\
\hline
\end{tabular}

In the structure column $\mathrm{x}$ : $\mathrm{y}$ indicates $\mathrm{x}$ number of carbon atoms in the fatty acid chain with $y$ number of double bonds. Due to their varying compositions, the properties of vegetable oil differ from each other and therefore their performance as engine fuel also differs.

\subsection{Biodiesel from vegetable oil}

Attempts have been made to overcome these problems which may be categorized in two ways; one is to modify the engine according to the properties of the oil involved, another is to develop vegetable oil derivatives that have the similar properties of hydrocarbon based diesel fuels. The modified engines built by Elsbett in Germany and Malaysia and Diesel Morten und Getraetebau GmbH in Germany and in the USA show a good performance when fuelled with vegetable oils of different compositions and grades. Among the 4 methods that are generally applied in developing vegetable oil derivatives namely: heating (pyrolysis), dilution (blending), emulsification and trans-esterification, it is found that converting vegetable oils into simple esters (by trans-esterification) is an effective way to overcome most of the problems. Transesterification is the reaction of a fat or oil with an alcohol to form ester and glycerol in the presence of an alkali or acid catalyst. Alkali catalyzed reaction is much faster than acid catalyzed reaction. This process is discussed briefly in section 4.1 .

\subsection{Use of Biodiesel and Energy Policies}

Biodiesels have been in use in Europe to a much larger extent particularly in Germany, France and Italy. While each individual country has its own energy policy, European Union (EU) established proposed targets for biodiesels to constitute $5.75 \%$ of transport fuels by 2010 and $10 \%$ by 2020. The U.S. Energy Independence and Security Act of 2007 (EISA) has established specific volumetric requirements for biomass-based diesel fuel up to 1.0 billion gallons/year (bg/y) by 2012. Several States are also actively pursuing policies to promote greater use of biodiesels. For example, California is developing a Low Carbon 
Fuels Standard (LCFS) and has recently passed legislation to address global warming concerns. Meeting California's LCFS and Green House Gas (GHG) reduction goals will require extensive use of biodiesels.

As current global biodiesel production stands at approximately $3.0 \mathrm{bg} / \mathrm{y}$, some countries are developing policies to promote greater use of biodiesel. Among them Brazil, China, and India are the three most significant. Collectively the policy-driven biodiesel requirements for the U.S., Europe, Brazil, China and India aimed at totalling approximately $23 \mathrm{bg} / \mathrm{y}$ by 2020 . The production and use of biodiesels have increased in different countries around the world as administered by their respective national energy policy which generally included the following factors:

- National energy security

- Diversity of energy sources emphasizing renewable sources

- Desire for sustainable energy sources

- Concerns over greenhouse gas (GHG) and global climate change

- Rural economic development

- Improved balance of trade

\section{Mustard Oil around the World}

Different varieties of mustard plants are cultivated around the world. White mustard (Sinapis hirta) grows in North Arica, Middle East and Mediterranean Europe; brown or Indian mustard (Brassica juncea) originated from the foothills of the Himalaya is grown in UK, Canada and the US; black mustard (Brassica nigra) is grown abundantly in the US, Argentina, Chile, some European countries and in Nepal, India and in Bangladesh. There are also some other varieties: yellow mustard (Sinapis alba) grown for its seed, turnip mustard (Brassica rapa) widely cultivated as leaf vegetable etc. (Simon, et al., 1984). Canada grows about $90 \%$ of all the mustard seed for the international market. The Canadian province of Saskatchewan produces almost half of the world's supply of mustard seed. Mustard oil could be produced from the seeds of black, brown and white mustard. As Canada produces large quantities of mustard seeds but mustard oil does not meet Canadian specifications for edible purposes, several researches have been performed in Canada to find out its alternate uses. From a research carried out in the department of Chemical Engineering of the University of Saskatchewan showed that biodiesel produced from mustard oil demonstrated a great potential as lubricant additive. This is due to the presence of mustard oil methyl ester (MOME). With an addition of 1\% MOME, lubricity was improved by $43.7 \%$ (Sarala et al. 2012).
As mustard oil has a much lower cloud point (of $3.5^{\circ} \mathrm{C}$ ) and pour point (of $-15^{\circ} \mathrm{C}$ ) than biodiesel made from animal fats or tropical oils like palm oil, mustard based biodiesel has an advantage in cold climates. To determine the best alternative fuel for diesel engines, an experiment was conducted with a diesel engine generator, at the Siddha Siddhanta Yoga Academy in Goverdhan, India which turned out that the best substitute for diesel was mustard oil (Naredi 2001). As a result, about half of the number of tractors in Govardan and parts of Mathura in India are now being operated on pure mustard oil. It is reported that the overall cost of running the engine in mustard oil is reduced as the required amount of lubricating oil is reduced.

At the University of Idaho besides canola and soybeans, extensive researches were carried out with mustard oil. Research showed that mustard oil based biodiesel performed very well in vehicles. On road testing about 58,800 $\mathrm{km}$ of running with a 2001 Volkswagen 1.9L diesel engine, fuel consumption was $16.3 \mathrm{~km} /$ liter, slightly higher than that of fossil diesel (Peterson \& Thompson 2005). In addition it was also showed that mustard can grow in drier areas and needs fewer pesticides and other agricultural inputs than canola. The University of Concepcion in Chile has founded research to discover the potential of mustard as source of oil to produce biodiesel. It shows that mustard yielding 40 quintal per hectare of land from which $50 \%$ of oil for biodiesel could be produced.

In Bangladesh during the last decade, as the demand of electricity and price of fossil fuels increased, several attempts were made to find out alternate and sustainable solutions to these problems in various research institutes. With a view to study the performance of small diesel engines, experiments were carried out (and also some are ongoing) as parts of undergraduate and post graduate researches in the department of Mechanical Engineering at BUET with mustard oil (Ehsan et al. 2007; Alam et al. 2010; Hasib et al. 2011a; Hasib et al. 2011b; Uddin 2013)

\subsection{Engines running with pure mustard oil in Bangladesh}

Some investigations and surveys were performed on some areas in Bangladesh where local people make use of indigenous machinery. In some northern parts of Bangladesh, single cylinder diesel engines have been in use for operating irrigation pumps and small electricity generators. Moreover, locally made small three wheeler transport vehicles using small diesel engines are usually plying in those areas. The small diesel engines which are very popular in the countryside for the above mentioned uses were primarily imported from China. After some years of operation, when the engine's performance is reduced, parts such as pistons made by local manufacturers are replaced. 


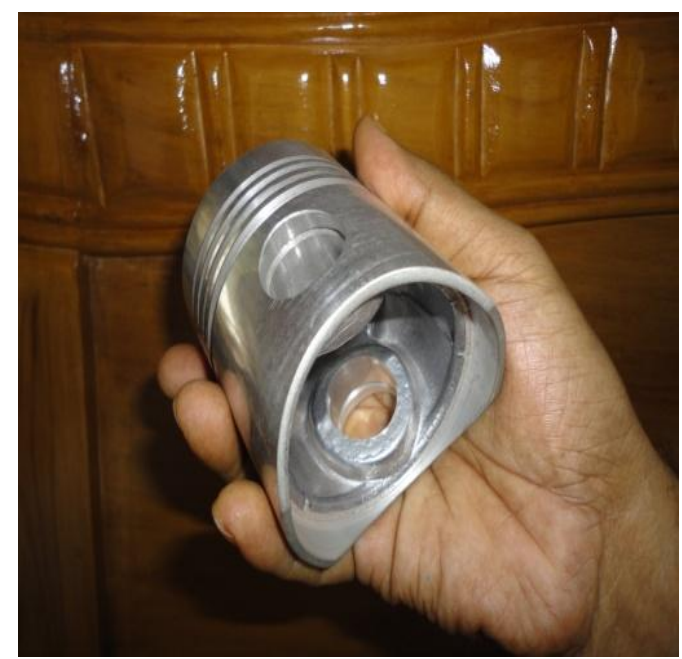

Fig.1 Piston manufactured locally in Bangladesh

It is observed that sometimes those remote areas have scarcity in diesel fuel. Following the example of Govardan and Mathura in India, such engines were found modified by local workshops for using edible grade mustard oil directly. Surveys on those areas showed that local people are happy with the performance of such engines operated by fresh mustard oil, even though the price of mustard oil is slightly higher than the price of diesel. A careful inquiry on this issue reveals that the overall expenses on running such small engines become lower with fresh mustard oil. The local people are usually reluctant to buy a new engine or to repair the worn out engine except only to change the piston. These pistons are locally manufactured by the Small and Medium Entrepreneurs called SMEs. One of such piston is shown in Fig. 1. The fresh mustard oil's high viscosity performs better in worn engines diminishing the need for extra lubricating oil and thus reducing cost. The preheating of the fresh mustard oil is done by modifying the heat exchanger of the engine's cooling system.

\subsection{Research on engine parts manufactured locally}

Some investigations were made on engine parts manufactured by SMEs under Pohl Consulting \& Associates of Germany in collaboration with the Department of Mechanical Engineering of BUET. It is observed that good quality metal alloys cheaply available from the scraps of ship breaking industries are used as raw materials for these parts. The cost of production is also less as the parts are not manufactured with high accuracy. The retail price of the piston shown in Fig. 1 is Taka 120, equivalent to US $\$ 1.5$, i.e., only $1 / 6^{\text {th }}$ of the price of actual Chinese piston. Moreover, the worn out pistons are bought back by the SMEs. Thus the reduction in engine performance and its longevity due to the part's inaccuracy is compensated by its running cost.
With this background information as described above, various researches related to its properties, laboratory testing and engine performances etc. are presented in this paper in the following sections. Subsequently in the next sections, parameters of crop cultivation and oil production criteria are discussed with a comparison to related matter to establish its sustainability for use in Bangladesh.

\section{Mustard Based Biodiesel Research in Bangladesh at BUET}

Branded and sealed bottled food grade mustard oil is used throughout the research at Bangladesh University of Engineering \& Technology (BUET) to determine its properties and performance testing. It is used instead of loose raw cheaper product to avoid impurities and contaminations

\subsection{Production of mustard based biodiesel}

Mustard based biodiesel is produced by the transesterification reaction. It is prepared in the laboratory according to Dr. Peeper's method [1]. First of all, the mixture of $250 \mathrm{ml}$ of methanol $\left(\mathrm{CH}_{3} \mathrm{OH}, 90 \%\right.$ pure $)$ and $150 \mathrm{ml}$ of sodium hydroxide $(\mathrm{NaOH}, 1 \mathrm{~N})$ is swirled in a glass container until $\mathrm{NaOH}$ is fully dissolved in methanol. This solution is known as methoxide and due to its exothermic nature, heat is generated.

Next, 1 liter of pure mustard oil, preheated to about $55^{\circ} \mathrm{C}$ is added to this hot methoxide. After that the mixture is jerked for about 5 minutes in a glass container.

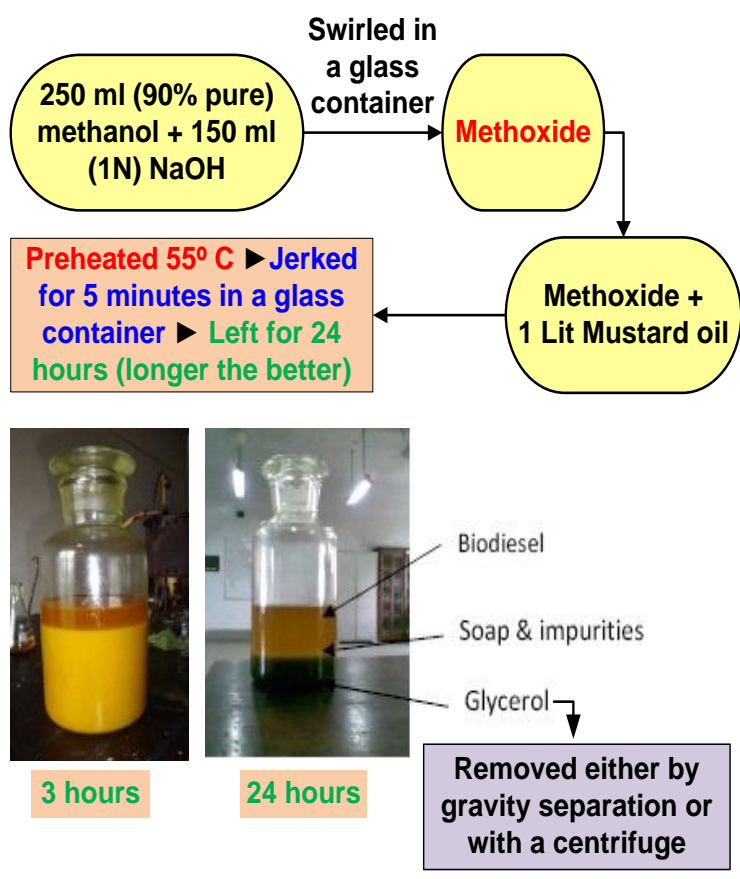

Fig. 2 Mustard oil based Biodiesel production 
Then the mixture is left for at least 24 hours (the longer the better) for separation of biodiesel and glycerol. The mixture is gradually settled down in distinctive layers. The upper more transparent layer is $100 \%$ biodiesel and the lower concentrated layer is glycerol. In some cases if the mustard oil contains impurities, a thin white layer is created in between the two layers, which constitutes soap and other impurities. The whole process is briefly presented in Fig. 2 in which the left picture shows two distinctive layers formed after 3 hours and the right picture shows three distinctive layers formed after 24 hours. The lighter layer is removed from the lower layer by gravity separation and $100 \%$ pure mustard based biodiesel is obtained. Biodiesel produced in this process contains moisture, methanol and soap. These are removed by heating the biodiesel at temperature above $100^{\circ} \mathrm{C}$. Then the pure biodiesel is blended with fossil diesel in different proportions.

\section{Fuel Properties of Mustard Based Biodiesel}

Mustard based biodiesel has slightly different fuel properties than those of conventional fossil diesel. A comparative study of fuel properties for fossil diesel, pure biodiesel (B100) and their blends (B20, B30, B40, B50) have been carried out in this work.

\subsection{Cloud Point and Pour Point}

Cloud point and pour point are important properties of fuel which should be taken into account when operating machineries at comparatively low temperatures. The cloud point of a fluid is the temperature at which dissolved solids are no longer completely soluble, precipitating as a second phase. In the petroleum industry cloud point refers to the temperature below which wax in diesel or bio-wax in biodiesel form a cloudy appearance. The presence of solidified waxes thickens the oil and clogs fuel filters and injectors in engines. The cloud point is determined in the laboratory following the manual method equivalent to ASTM D2500. The test sample is poured into a test jar to a level approximately half full. A cork carrying the test thermometer is used to close the jar. The thermometer bulb is positioned to rest at the bottom of the jar. At every $1^{\circ} \mathrm{C}$, the sample is taken out and inspected for cloud then quickly replaced until the desired result is obtained.

The pour point of a liquid is the lowest temperature at which it becomes semi solid and loses its flow characteristics. In general a high pour point is associated with high paraffin content, typically found in crude oil deriving from a larger proportion of plant material. The pour point is determined in the laboratory following the manual method equivalent to ASTM D97. The specimen is cooled inside a cooling bath to allow the formation of paraffin wax crystals. At about $9{ }^{\circ} \mathrm{C}$ above the expected pour point, and for every subsequent $3{ }^{\circ} \mathrm{C}$, the test jar is removed and tilted to check for surface movement. When the specimen does not flow when tilted, the jar is held horizontally for 5 seconds. If it does not flow, $3^{\circ} \mathrm{C}$ is added to the corresponding temperature and the result is the pour point temperature. Cloud point and pour point as determined by the methods described above for pure mustard based biodiesel are found respectively $-6^{\circ} \mathrm{C}$ and $-13{ }^{\circ} \mathrm{C}$.

\subsection{Flash point and Fire Point}

Standard testing method ASTM D90 has been applied to detect flash point and fire point. Table 3 shows a comparison of flash point and fire point between pure biodiesel and fossil-diesel.

Table 3

Flash point and Fire point

\begin{tabular}{ccc}
\hline Fuels & $\begin{array}{c}\text { Flash point } \\
\left({ }^{\circ} \mathbf{C}\right)\end{array}$ & $\begin{array}{c}\text { Fire point } \\
\left({ }^{\circ} \mathbf{C}\right)\end{array}$ \\
\hline $\begin{array}{c}\text { Pure mustard oil biodiesel } \\
(\text { B100) }\end{array}$ & 55 & 72 \\
Fossil diesel & 52 & 65 \\
\hline
\end{tabular}

\subsection{Viscosity}

Viscosity of the fuel exerts a strong influence on the shape of the fuel spray; high viscosity for example, causes low atomization (large-droplet size) and high penetration of the spray jet. Note that a cold engine, with higher viscous oil, discharge wills almost a solid stream of fuel into the combustion chamber and starting may be difficult while a smoky exhaust will almost invariably appear. On the other hand, very low viscous fuel would cause to pass thorough the leakage of piston and piston wall especially after wear has occurred, which subsequently prevents accurate metering of the fuel.

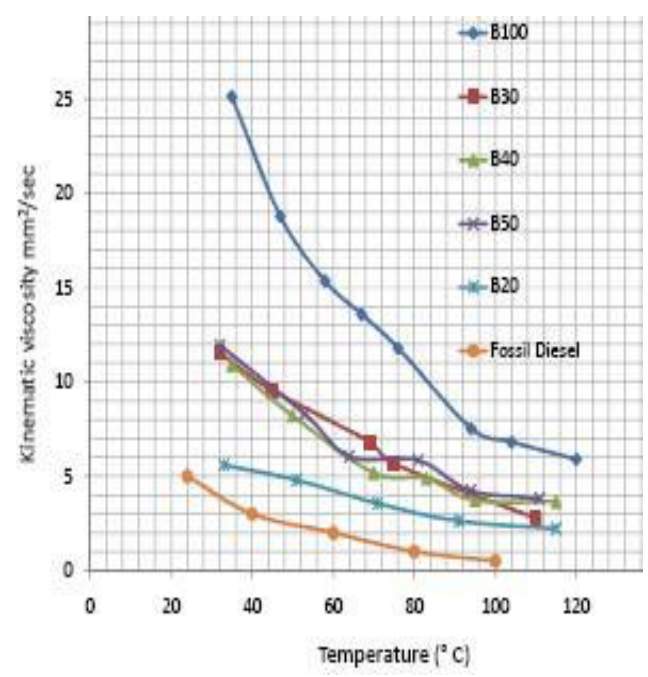

Fig. 3 Temperature vs. kinematic viscosity for diesel, biodiesel and their blends 
Standard testing method ASTM D445 has been applied to measure the viscosity of different fuels. Fig. 3 indicates that, B20 has 1.5 times higher viscosity than fossil diesel at the room temperature. On the other hand, B30, B40 and B50 have almost the same viscosity at room temperature, and it is about 2.5 times higher than the fossil diesel. But a slight preheating would cause to achieve comparable viscosity as that of diesel fuel. So using B20, B30, B40 and B50 blend would not cause much change in the fuel spray pattern, and thus these fuels can be used in the existing diesel engines without modification of the fuel supply system.

Also it is observed that B100 is a much viscous fuel, and its viscosity is about 6 times higher than that of diesel fuel. The high viscous fuel would exhibit almost a solid stream of spray pattern in the combustion chamber and so cold starting of the engine would be difficult. So, using B100 fuel in the existing diesel engine would require modification of the fuel supply system so that the fuel supply system exerts high spray pressure to achieve the desired spray pattern inside the engine cylinder.

\subsection{Heating Value}

Heating value indicates the energy density of the fuel. In this study, ASTM 2382 method has been applied to measure the heating value of biodiesel and their blends. Table 4 shows the heating value of diesel, neat biodiesel and their blends in MJ/Kg. From Table 4 it is observed that, diesel fuel has heating value about 44 $\mathrm{MJ} / \mathrm{Kg}$. Heating values of the fuel decreases as we choose higher blending of biodiesel. As heating value of the fuel decreases for higher blending of biodiesel, consumption of fuel also increases for higher and higher blending of biodiesel. This is because, as biodiesel has lower energy density than diesel fuel, so higher amount of biodiesel is required for producing same amount of energy as compared to diesel fuel.

Table 4

Comparison of heating value of different fuels

\begin{tabular}{cc}
\hline \multicolumn{1}{c}{ Heating value (MJ/Kg) } \\
\hline Fossil Diesel & 44.00 \\
Neat biodiesel B100 & 39.51 \\
B50 & 41.97 \\
B40 & 42.18 \\
B30 & 42.21 \\
B20 & 42.65 \\
\hline
\end{tabular}

\section{Engine Performance}

Various performance tests have been carried out in the Heat Engine laboratory with a single cylinder directinjection diesel engine the specification of which are presented in Table 5 and the experimental setup is shown in Fig. 4.

The engine is operated at a constant speed of 2200 RPM at varying load conditions between 1 to $3 \mathrm{~kg}$. Lubricating oil used is SAE 40. Tested fuels are 100\% -

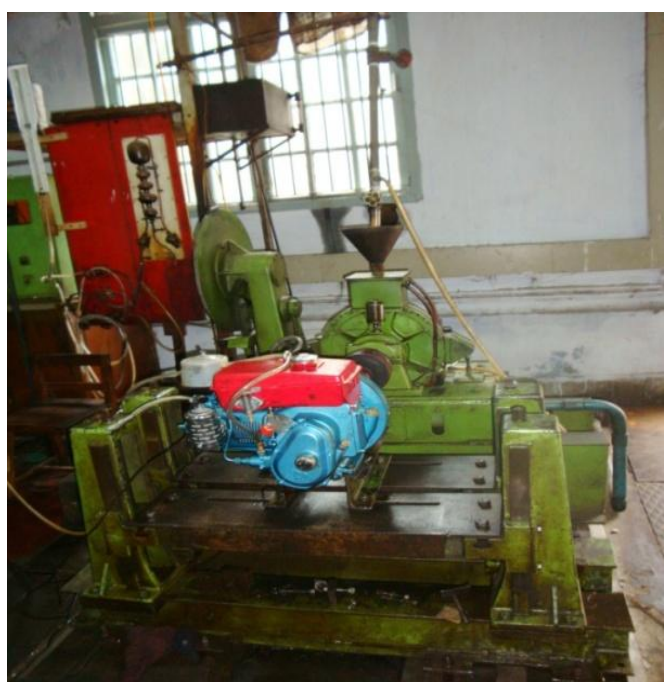

Fig. 4 Experimental setup

Table 5

\begin{tabular}{ll} 
Engine Specifications & Z170F \\
\hline Model & $\begin{array}{l}\text { Horizontal, single cylinder, four } \\
\text { stroke, air cooled }\end{array}$ \\
\hline Type & $\begin{array}{l}\text { Double bird co. Ltd., China } \\
\text { Pre-burning type swirl combustion } \\
\text { chamber }\end{array}$ \\
Combustion model & $70 \mathrm{~mm}$ \\
Cylinder diameter & $70 \mathrm{~mm}$ \\
Piston stroke & $2600 \mathrm{rpm}$ \\
Nominal Speed & $3.23 \mathrm{Hp}$ \\
Nominal Power & Hand cranking or starting mode \\
Starting mode & $40 \mathrm{~kg}$ \\
Net weight & $520 \times 335 \times 425$ \\
Dimensions, mm & $18 \sim 20.5$ \\
Compression ratio & \\
Specific fuel consumption & 285.6 (g/ Kw.h) \\
at rated output & \\
Specific lube oil & 4.75 (g/ Kw.h) \\
consumption & Universal coupling \\
Coupling & Anti clock wise \\
Rotation &
\end{tabular}

diesel, B20, B30, B40, B50 and pure biodiesel (B100). A hydraulic brake dynamometer directly coupled with the engine was used to load the engine.

Load was varied by changing the water flow rate to the dynamometer. Fuel was supplied from externally installed tank, allowing volume measurement of fuel consumed. Fuels were feed to the injector under gravity. Fuel supply system was modified, so that fuels could be supplied from a graduated burette instead of the fuel tank when needed. Fuel consumption rate was recorded by observing the time using a stop watch for every 50 $\mathrm{ml}$ of fuel. Speed was measured by digital tachometer. Exhaust, lube oil and fuel inlet temperatures were measured by using K-type thermocouple. Preheating was done manually using gas burner. 
Preheating is necessary because the viscosity of B40, B50 and B100 has much higher viscosity than fossil diesel at room temperature. With high viscosity of fuel, the jet trend to be a solid stream instead of spray o small droplets. As a result, fuel is not mixed with air required for combustion. This results in poor combustion accompanied by loss of power and economy.

\subsection{Performance characteristics and discussions}

Following performance characteristic have been investigated in this experimental study. All the test results are derived as per BS 5514 standard. The performance parameters are as follows:

- Break horse power (BhP)

- Brake specific fuel consumption (Bsfc)

- Brake thermal efficiency

Fig. 5 shows the relation between Brake specific fuel consumption, Bsfc and brake horse power, Bhp for different fuel blends. Bsfc is a measure of overall efficiency of the engine and is inversely related with efficiency. So, lower the value of Bsfc, higher is the overall efficiency of the engine. From the Fig., it is evident that Bsfc for biodiesel blends is always higher than that of diesel fuel. That means, efficiency for B100 is $20 \%$ less than the fossil diesel. B20 and B30 has about 10 12\% less efficient than diesel. So using B20 and B30 is economically viable than neat biodiesel B100. This is because biodiesel has lower heating value than conventional diesel fuel. Another cause for lower values for biodiesel blends is the poor atomization which is attributed to higher density and kinematic viscosity of biodiesel blends. The curve also shows that, Bsfc for biodiesel blends is lower as \% load is increased.

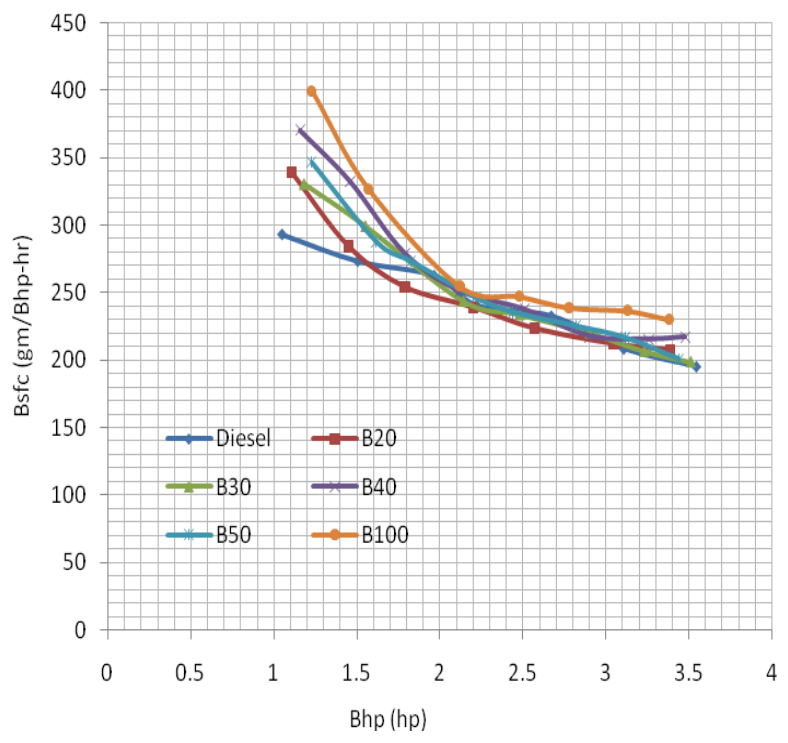

Fig. 5 Variation of Bsfc with Bhp for different blends
Therefore, as the Bhp increases the variation is reduced and all blends tend to produce similar effect. This is very advantageous to use mustard based biodiesel as an alternate to diesel in a sense that once after start (even if there is difficulty at the beginning) the engine is capable of running without difficulty as the load is increased and performance tends to become close to diesel fuel.

\subsection{Cost comparison}

In Bangladesh, present market price of diesel is slightly lower than that of pure food grade mustard oil. So it is clear that, running diesel engine with biodiesel blends is costly as compared to diesel fuel. But it should be kept in mind that, in Bangladesh, government grants a huge subsidy on diesel fuel, which causes the lower price for diesel fuel. Therefore, in actual comparison international market price of diesel is to be considered. Also commercial production of biodiesel made from non-food grade mustard oil may further reduce its production cost. Traditionally village people still use locally made simple grinding mill to produce mustard oil as shown in Fig. 6. Therefore, improving the mill would reduce its production cost when produced in large scale.

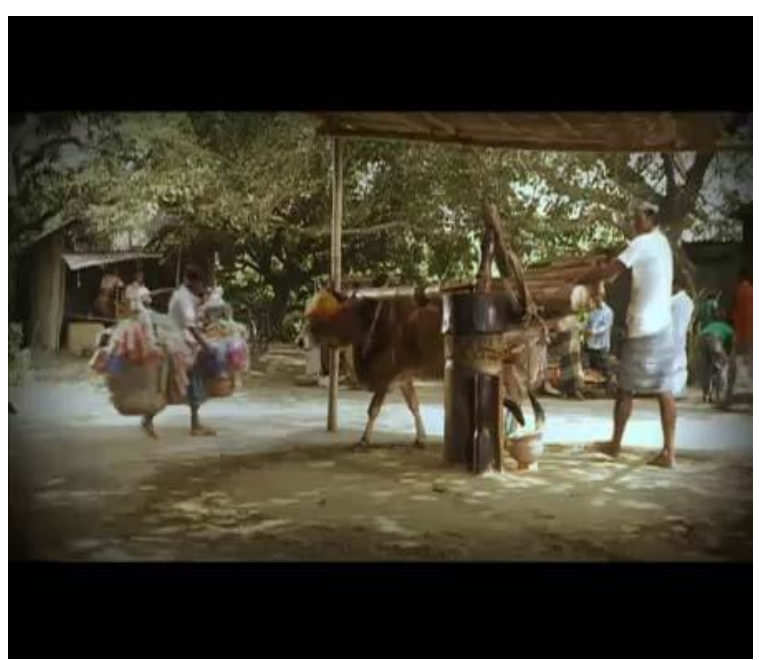

Fig. 6 Mustard oil grinding mill operated by a cow

\subsection{Comparison with other feedstock for biodiesel}

In the present context of Bangladesh, mustard seed is the best suitable feedstock than any other feedstock for biodiesel production. Jatropha is another promising seed to produce biodiesel. The advantages of using mustard oil over jatropha are listed as below:

- At present cultivation method of jatropha is not well developed in Bangladesh, but almost all the districts of Bangladesh are suitable for mustard cultivation. 
- Jatropha shrub requires enough rainfall for its proper growth. But for mustard plantation, small rainfall is sufficient for good harvest.

- Jatropha seeds requires long time to mature and its crushing is not as easy as crushing of mustard seeds for extraction of oil

- Jatropha is not an annual plant and requires much area than mustard.

\section{Conclusions}

In Bangladesh the improving standards of living and as a consequence, increasing demand for electricity and high price of fossil fuel has prompted many researches to find out various alternative and renewable energy sources. As mentioned earlier, this is also enhanced by the government's newly prepared RE policy targeting to develop renewable energy resources to meet $5 \%$ of the total power demand by the year 2015 and $10 \%$ by the year 2020. Previous relevant researches and the present study have shown that mustard based biodiesel has many significant characteristics to be a preferred sustainable renewable energy source for Bangladesh. In addition to general benefits of vegetable oils as mentioned in Section 2 and from the test results shown in Section 5, mustard oil has some additional benefits that lead to the following conclusions in 3 categories:

\subsection{Sustainability by Oil Properties}

- Biodiesel made from mustard oil has its cloud point $-6^{\circ} \mathrm{C}$ and pour point $-13^{\circ} \mathrm{C}$, far above the minimum temperature in Bangladesh during winter season. So, it is possible to run diesel engines with mustard based biodiesel without anti-gel or pour point depressant even in winter.

- Although pure biodiesel (B100) has a higher viscosity, the problem is resolved by blending it with fossil diesel.

- Mustard based biodiesel has got some similarity in its composition with crambe oil, which is used as an industrial lubricant. Thus it requires a minimum amount of lubricating oil when operating the locally fabricated small diesel engines. This is also validated by the results of similar research conducted in India.

\subsection{Engine performance}

- Engine performance with mustard based biodiesel does not deviate much from the performance with diesel fuel except in low loading conditions.
- Due to its slightly lower heating value of biodiesel compared to diesel fuel, a slightly higher amount of biodiesel is required to run the engine.

- The fresh mustard oil may be used in worn out engines only. The fresh oil's high viscosity performs better in such engines diminishing the need for extra lubricating oil.

\subsection{Concluding remarks}

In the past, when import of cheaper soybean oil began in the country, demand of mustard oil was drastically dropped but its cultivation was not ended totally. This is because of the fact that, it's sowing and harvesting time lies in between two major crops of Bangladesh. It is sown between mid-October and midNovember and harvested between late January and mid-February. This is exactly in match with the high yielding variety crops of rice and jute That means, if the land is not used for mustard cultivation, it would otherwise be remained idle. The present research concerning its properties and engine performance demonstrates that mustard oil would become the most significant renewable energy source of Bangladesh. Considering its diverse uses and favorable agricultural constraints, mustard cultivation has already established its prosperity in Bangladesh. To make mustard a substantial contributor in improving Bangladesh's overall economical condition, appropriate measures should be considered in adapting various regulations in RE policies to support its sustainability and to encourage further research.

\section{Acknowledgement}

This paper used the results obtained from research works by the students of Mechanical Engineering Department of BUET under the supervision of the author and materials from subsequent published papers. Experiments were performed in Fuel Testing and Heat Engine laboratories of the Department and funded by BUET.

\section{References}

Alam, M.M, Hasib, Z.M., Rahman, K.A. \& Alam, M.S. (2010) Bio-diesel from Mustard Oil: A Renewable Alternative Fuel for Small Diesel Engines" Proc. of International Conference on Sustainable Mobility, ICSM, Kuala Lumpur, 1-3 December, 9, 19-27.

Arjun, B.C. \& Islam, M.R. (2008) Inherently Sustainable Technology Developments, pp 216-217. Nova Science Publishing Inc., New York.

Bangladesh Bureau of Statistics (2011) Bangladesh Statistical Yearbook. Edition 30.

Batra, P. (2003) Evaluation of Mustard oil as a Health oil in Rat Model. PhD Thesis, Department of Medical Elementology and Toxicity, Hamdard University, India.

Ehsan, M., Taposh, R.M. \& Islam, M.M. (2007) Running a Diesel Engine 
with Biodiesel. Proceedings of the 7th International Conference on Mechanical Engineering, ICME 2007-TH 34. pp. 1-4

Forhad, A., Rowshan, A.R., Habib, M.A. \& Islam, M.A. (2009) Production and Performance of Biodiesel as an Alternative to Diesel International Conference on Mechanical Engineering, ICME, No.TH30. pp. 1-6.

Hasib, Z.M., K.A. Rahman \& Alam, M.S. (2011a) Prospect of Bio diesel production from Mustard oil. B.Sc. Engineering Thesis, Bangladesh University of Engineering and Technology, Dhaka, Bangladesh.

Hasib, Z.M., Hossain, J., Biswas, S. \& Islam, A. (2011b) Bio-diesel from Mustard Oil: A Renewable Alternative Fuel for Small Diesel Engines. Scientific Research, Modern Mechanical Engineering, 1 77-83.

Mani N. (2010) An Investigation of Vegetable Derived Biodiesel as Potential Blendstocks for Transportation Fuels. Proceedings of International Conference on Sustainable Mobility, December Kuala Lumpur, Malaysia, pp. 1-18
Naredi A.V. (2001) Best Alternative for Diesel-Mustard Oil, Siddha Siddhanta Yoga Academy, Govardan, India pp. 1-2.

Peterson, C.L. \& Thompson, J. (2005) Biodiesel from Mustard oil. Final Report No. 05-06, National Institute for Advanced Transportation Technology, University of Idaho.

Sarala, R., Rajendran, M. \& Devadasan, S.R. (2012) Emission characteristics of Mustard Oil Methyl Ester (MOME)-Diesel fuel blends on a C.I Engine' Int. Journal of Green Chemistry and Bioprocess, 6-10.

Simon, J.E., Chadawick, A.F. \& Craker, L.E. (1984) Herbs: An Indexed Bibliography 1971-1980, Archon Books, New Haven, USA.

Srivastava, A. \& Prasad, R. (2000) Triglyceride-based diesel fuels Renewable and sustainable Energy Reviews, 4(2), 111-133.

Uddin S.M.A. (2013) Performance of Biodiesel from Mustard oil as an Alternative Fuel for Diesel Engine. M.Sc. Engineering Thesis, Department of Mechanical Engineering, Bangladesh University of Engineering and Technology, Dhaka, Bangladesh. 